\title{
Pengisian Jabatan Gubernur Di Indonesia (Solusi Alternatif)
}

\author{
Imran
}

\section{Dosen Fakultas Hukum Universitas Tadulako, Palu}

\begin{abstract}
Abstrak
Konstruksi perwilayahan yang dianut dalam Undang-Undang Nomor 32 Tahun 2004 Tentang Pemerintahan Daerah, menempatkan Provinsi sebagai daerah otonom, sekaligus menempatkan Gubernur sebagai wakil Pemerintah. Oleh sebab itu, Gubernur memiliki status ganda yakni sebagai kepala pemerintah daerah provinsi dan sebagai wakil Pemerintah yang melaksanakan tugas-tugas dekonsentrasi di wilayah provinsi. Dari kedudukan Gubernur yang mengembang dual function tersebut, sejatinya tercermin dalam model pengisian jabatan Gubernut. Gubernur dalam kedudukannya sebagai kepala daerah otonom dipilih langsung oleh rakyat, yang berarti mempunyai legitimasi lebih kuat dari pada model pemilihan yang lainnya (melalui DPRD), sehingga ekspektasi rakyat atas keterlibatannya secara langsung dalam pemilihan Gubernur menjadi dasar bagi rakyat untuk selalu mengawasi pelaksanaan tugas, fungsi dan wewenang Gubernur dalam penyelenggaraan urusan pemerintahan daerah. Sedangkan Gubernur sebagai wakil Pemerintah, berarti melaksanakan tugas-tugas yang dilimpahkan kepada Gubernur sebagai pejabat pusat di daerah. Gubernur dalam melaksanakan tugasnya sebagai wakil Pemerintah Pusat senantiasa berada dalam pengawasan dan bertanggungjawab kepada Pemerintah Pusat. Oleh sebab itu, dalam pengisian jabatan Gubernur, Pemerintah Pusat sejatinya juga mempunyai peranan dalam memastikan Gubernur yang akan dipilih oleh rakyat mempunyai kapabilitas untuk melakukan tugas-tugas sebagai wakil Pemerintah di wilayah provinsi. Karena itu, model pengisian jabatan Gubernur merupakan kombinasi antara pemilihan langsung dengan model pengangkatan semu. Pemilihan Gubernur secara langsung adalah model pengisian jabatan Gubernur yang tepat guna membentuk keseimbangan dan kontrol atas kedudukan gubernur sebagai pejabat pusat pada satu sisi dan sebagai pejabat derah otonom pada sisi lainnya. Pemilihan Gubernur secara langsung, setidaknya akan membentuk kemandirian berhadapan dengan Pemerintah Pusat, mengingat kedudukan Gubernur sebagai pejabat daerah otonom yang dipilih secara langsung oleh rakyat. Selain itu, Pemilihan Gubernur secara langsung juga dapat menciptakan perimbangan antara berbagai kekuatan dalam penyelenggaraan negara terutama dalam menciptakan mekanisme checks and balances antara Kepala Daerah dengan lembaga perwakilan (DPRD) karena sama-sama dipilih oleh rakyat.
\end{abstract}

Keyword: Otonomi Daerah, Pemilukada, dan Model Pengisian Jabatan Gubernur. 


\section{Pendahuluan}

Diskursus mengenai pengisian jabatan Gubernur (baca: pemilihan Gubernur), akhir-akhir ini memang menjadi wacana pemikiran alternatif, apakah Gubernur tetap dipilih langsung oleh rakyat, dipilih melalui DPRD, atau diangkat oleh Presiden. Seperti misalnya pemikiran di kalangan Pemerintah, khususnya Kementerian Dalam Negeri, untuk mengubah sistem pemilihan langsung Gubernur menjadi tak langsung melalui DPRD ataupun ditunjuk langsung oleh Presiden. ${ }^{1}$ Wacana pemikiran ini, selain didasarkan pada alasan efisiensi dan efektivitas penyelenggaraan pemerintahan daerah, juga atas dasar pertimbangan bahwa Gubernur itu mengemban "dual function" sebagai kepala pemerintah daerah provinsi ${ }^{2}$ dan sebagai wakil Pemerintah di wilayah provinsi. $^{3}$

Menanggapi

wacana

pemikiran tersebut, Presiden Susilo Bambang Yudhoyono dalam suatu acara di Lembaga Ketahanan Nasional, Presiden menegaskan bahwa usul pemilihan Gubernur dan Wakil Gubernur dipilih oleh DPRD masih merupakan "pilihan terbuka", kemungkinan itu sama terbukanya dengan mempertahankan pemilihan langsung. ${ }^{4}$ Meskipun menegaskan sebagai "pilihan terbuka", pernyataan Presiden seperti kata bersayap, yaitu dengan meminta semua pihak merujuk kembali pada konstitusi. Ini berarti, hal ichwal

\footnotetext{
${ }^{1}$ Lihat: harian Kompas, 26 November 2010.

${ }^{2}$ Lihat: UU Nomor 32 Tahun 2004 Tentang Pemerintahan Daerah, Pasal 24 ayat (2), menyebutkan bahwa "Kepala Daerah... untuk provinsi disebut Gubernur...”.

3 Lihat: Pasal 37 dan Pasal 38 UU Nomor

32 Tahun 2004.

${ }^{4}$ Lihat: harian Kompas, 14 Desember 2010.
}

mengenai pemilihan Gubernur tersebut, secara tekstual harus diletakkan dalam konteks ketentuan Pasal 18 ayat (4) UUD NRI Tahun 1945 yang mengatur bahwa "Gubernur, Bupati, dan Walikota masing-masing sebagai kepala pemerintah daerah provinsi, kabupaten, dan kota dipilih secara demokratis".

Sekalipun Pasal 18 ayat (4) UUD 1945 menyatakan bahwa "...gubernur dipilih secara demokratis". Namun pilihan politik pembentuk undang-undang telah mempersempit makna frasa kata "dipilih secara demokratis" menjadi pemilihan secara langsung. ${ }^{5}$ Ketentuan Pasal 24 ayat (5) UU Nomor 32 Tahun 2004 menegaskan bahwa "Kepala daerah dan wakil kepala daerah ... dipilih secara langsung oleh rakyat di daerah yang bersangkutan". Pasal 56 UU Nomor 32 Tahun 2004 menyebutkan bahwa "Kepala daerah dan wakil kepala daerah dipilih dalam satu pasangan calon yang dilaksanakan secara demokratis berdasarkan asas langsung, umum, bebas, rahasia, jujur, dan adil".

Masalahnya kemudian, sistem pemilihan Kepala Daerah dan Wakil Kepala Daerah sebagaimana dalam Undang-Undang Nomor 32 Tahun 2004, diatur secara seragam pada derajat otonomi yang berbeda. Otonomi yang berlaku pada daerah provinsi, memposisikan Gubernur sebagai pejabat daerah otonom, selain posisi Gubernur sebagai pejabat pusat di daerah, sehingga dalam menjalankan urusan

\footnotetext{
${ }^{5}$ UU Nomor 32 Tahun 2004, Pasal 24 ayat (5) menentukan bahwa "Kepala Daerah dan Wakil Kepala Daerah ...dipilih dalam satu pasangan secara langsung oleh rakyat di daerah yang bersangkutan”.
} 
pemerintahan berada pada dua sisi antara urusan Pemerintahan Daerah otonom dan urusan Pemerintah Pusat di daerah. Karena itu, model pengisian jabatan gubernur sejatinya dilakukan dengan mempertimbangkan kedudukan Gubernur serta derajat otonomi yang berlaku pada daerah provinsi.

\section{Pembahasan}

\section{Landasan Konstitusional Pengaturan Pemilukada Langsung.}

Dasar
pemilihan umum kepala daerah
(Pemilukada) langsung dimuat dalam
ketentuan Pasal 18 ayat (4)
Perubahan Kedua UUD NRI Tahun 1945 yang menentukan bahwa "Gubernur, Bupati, dan Walikota masing-masing sebagai kepala pemerintah provinsi, kabupaten, dan kota dipilih secara demokratis". Dari frasa kata "dipilih secara demokratis" dapat dimaknai bahwa pemilihan kepala daerah dapat dilakukan secara langsung maupun tidak langsung (melalui DPRD). Itu artinya, Pasal 18 ayat (4) UUD NRI Tahun 1945, bersifat luwes dan intrepretatif mengenai model pemilihan kepala daerah, tetapi tegas dalam menetukan syarat pemilihan, yakni harus dilakukan dengan cara yang "demokratis". Adapun mengenai syarat "demokratis" pemilihan kepala daerah dapat dimaknai sebagai demokratisasi tahapan pemilihan kepala daerah secara keseluruhan. ${ }^{6}$

6 Proses pemilukada yang dimulai dari proses penetapan daftar pemilih, penetapan calon, kampanye, pemungutan suara, penghitungan suara, penetapan hasil, bahkan terhadap perselisihan hasil semestinya
Sebagai penjabaran dan tafsir atas Pasal 18 ayat (4) UUD NRI Tahun 1945, ketentuan Pasal 24 ayat (5) UU Nomor 32 Tahun 2004, menegaskan bahwa "Kepala Daerah dan Wakil Kepala Daerah...dipilih dalam satu pasangan secara langsung oleh rakyat di daerah yang bersangkutan". Pasal 56 ayat (1) UU Nomor 32 Tahun 2004, menentukan bahwa "Kepala daerah dan wakil kepala daerah dipilih dalam satu pasangan calon yang dilaksanakan secara demokratis berdasarkan asas langsung, umum, bebas, rahasia, jujur dan adil".

Sebagai suatu legal policy dan pilihan politik pembentuk undang-undang, pengisian jabatan kepala daerah dan wakil kepala daerah secara langsung dimaksudkan dalam rangka melaksanakan amanat reformasi konstitusi yang menghendaki agar pengisian jabatan di setiap tingkatan dilakukan secara demokratis. ${ }^{7}$ menyebabkan tidak hanya Presiden dan Wakil Presiden yang dipilih secara langsung, tetapi pengisian jabatan kepala daerah dan wakil kepala daerah juga harus melalui mekanisme pemilihan secara langsung. ${ }^{8}$

Dalam konteks lebih luas, legal policy pembentuk undangundang memaknai frasa "dipilih secara demokratis" menjadi pemilihan langsung merupakan salah

dilaksanakan dalam kerangka "demokratis" yang diamanatkan oleh konstitusi.

Jazim Hamidi dan Mustafa Lutfi, Rethinking Penyelenggaraan Pilkada yang Demokratis dan Partisipatif, dalam Konstitusionalisme Demokrasi (Sebuah Diskursus tentang Pemilu, Otonomi Daerah dan Mahkamah Konstitusi sebagai Kado untuk 'Sang Penggembala' Prof. A.Mukthie Fadjar, SH., MS.), In-TRANS Publishing, Malang, 2010., hlm. 210

${ }^{8}$ Ibid. 
satu bentuk kongkret pelaksanaan asas kedaulatan rakyat. $^{9}$ Bagaimanapun, menggunakan sistem perwakilan, rakyat akan kehilangan kedaulatannya secara langsung menentukan kepala daerah. ${ }^{10}$ Praktik pengisian jabatan kepala daerah di masa lalu menjadi pelajaran berharga betapa pemilihan dengan sistem perwakilan acap kali mendistorsi kehendak dan logika rakyat.

\section{Sistim Pengisian Jabatan Kepala Daerah.}

Dalam konteks, pengisian jabatan Kepala Daerah Joko J. Prihatmoko membagi tiga jenis sistem pemilihan kepala daerah yakni : (1) sistem penunjukan dan/atau pengangkatan oleh Pemerintah Pusat; (2) sistem pemilihan perwakilan oleh DPRD; dan (3) sistem pemilihan langsung oleh rakyat. ${ }^{11}$

Metode atau cara yang digunakan dalam sistem pengisian jabatan Kepala Daerah dapat dikelompokkan menjadi dua jenis, yakni : (1) sistem pemilihan secara tidak langsung dengan mekanisme pengangkatan dan/atau penunjukan serta pemilihan perwakilan; dan (2) pemilihan secara langsung yakni memberikan ruang atau keleluasaan rakyat untuk memilih Kepala Daerah. $^{12}$

$$
\text { Dalam metode tidak }
$$
langsung, kedaulatan rakyat diserahkan/dititipkan pada elit politik, baik pemerintah/pejabat

\footnotetext{
${ }^{9}$ Saldi Isra, Haruskah Kembali Ke DPRD?, harian Kompas, 16 Desember 2010.

${ }^{10}$ Ibid.

11 Joko J. Prihatmoko, Pemilihan Kepala Daerah Langsung, Filosofi, Sistem dan Problema, Pustaka Pelajar, Yogyakarta, 2005, hlm. 104

${ }^{12}$ Ibid, hlm. 105
}

pusat atau parlemen.

Konsekuensinya, pertanggungjawaban dan bahkan pemberhentian Kepala Daerah juga bersifat tidak langsung. Sedangkan metode langsung, kedaulatan sepenuhnya diserahkan dan digunakan oleh rakyat sehingga lebih menjamin keterwakilan dan preferensi, yang lebih menimbulkan kesan lebih demokratis. ${ }^{13}$

Pemilihan Kepala Daerah secara langsung memiliki beberapa variasi model. Pertama, Two round system, yakni pemilih hanya memberikan pilihannya pada satu calon Kepala Daerah. Calon Kepala Daerah hanya dapat menduduki jabatan jika sudah mencapai 50 persen plus satu suara. Kedua, model aprroval, yakni yang memberikan peluang bagi pemilih untuk memilih semua (pilihan ganda) calon Kepala Daerah. Ketiga, model first past the post, yakni calon yang memperoleh suara terbanyak otomatis akan menduduki posisi sebagai Kepala Daerah betapapun suara yang dipilih sangat minimal. ${ }^{14}$

Model two round system, akan menghasilkan legitimasi Kepala Daerah yang maksimal, hanya saja memerlukan biaya dan waktu. Model first past the post memiliki legitimasi sangat rendah tapi sangat efisien. Namun kemungkinan Kepala Daerah yang menang hanya memperoleh suara kemenangan tipis. Model approval sebenarnya menjadi penengah dari kedua sistem di atas. Model ini tidak rumit dan dilakukan hanya satu kali putaran. Tapi karena seperti multiple choice, tidak semua orang bisa memahami bahwa

\footnotetext{
${ }^{13}$ Ibid, hlm. 106

14 Joko J. Prihatmoko, Mendemokratiskan Pemilu; dari Sistem sampai Elemen Teknis, Pustaka Pelajar, Yogyakarta, 2008, hlm. 241
} 
seseorang bisa memilih 2 atau 3 calon sekaligus. ${ }^{15}$

Pemilihan Kepala Daerah secara langsung merupakan mekanisme rekruitmen Kepala Daerah yang terbingkai dalam suatu sistem. Secara prosedural, pilkada langsung idealnya mengakomodasi sistem seleksi terpadu, yakni serangkaian seleksi yang saling melengkapi untuk melahirkan calon Kepala Daerah terpilih yang berkualitas, mulai dari seleksi sistem ketatanegaraan, partai politik, administratif, hukum administrasi, sampai seleksi politis. ${ }^{16}$

Pilihan terhadap mekanisme dan sistem yang digunakan dalam proses pengisian jabatan Kepala Daerah dipengaruhi oleh dua faktor yaitu: (1) bentuk pemerintahan negara; dan (2) sistem demokrasi pemerintahan atau sistem pemerintahan. ${ }^{17}$ Di negara-negara kesatuan, pengisian jabatan Kepala Daerah umumnya menggunakan sistem pengangkatan dan/atau penunjukan oleh pemerintah pusat atau sistem pemilihan tidak langsung atau sistem perwakilan melalui parlemen daerah karena sumber kekuasaan terletak di pemerintah pusat, sedangkan di negara-negara federal pemilihan kepala pemerintahan negara bagian lazimnya dipilih oleh rakyat karena dalam sistem federasi murni sumber kekuasaan terletak di daerah. ${ }^{18}$

Dari perspektif sejarah, pengisian jabatan Kepala Daerah di

\footnotetext{
${ }^{15}$ Ibid., hlm. 241-242

${ }^{16}$ Ibid., hlm. 196

17 Joko J. Prihatmoko, Pemilihan Kepala Daerah Langsung...Op.Cit., hlm. 107

${ }^{18}$ Ibid.
}

Indonesia telah dilakukan dalam empat sistem yakni: ${ }^{19}$

1. Sistem penunjukan atau pengangkatan oleh Pemerintah Pusat (masa pemerintahan kolonial Belanda, Pendudukan Jepang). Masa setelah kemerdekaan yakni berlakunya UU Nomor 1 Tahun 1945, UU Nomor 22 Tahun 1948 dan UU Nomor 1 Tahun 1957.

2. Sistem penunjukan (Penetapan Presiden No. 6 Tahun 1959 jo. Penetapan Presiden Nomor 5 Tahun 1960; UU Nomor 61959 dan UU Nomor 18 Tahun 1956), Dekrit Presiden 5 Juli 1959, yang lebih dikenal dengan era Demokrasi Terpimpin;

3. Sistem pemilihan perwakilan (UU Nomor 5 Tahun 1974), era demokrasi Pancasila. Pilkada dilakukan oleh DPRD, tetapi calon yang dipilih itu finalnya tetap ditentukan oleh Presiden.

4. Sistem pemilihan perwakilan (UU Nomor 18 Tahun 1965 dan UU Nomor 22 Tahun 1999), dimana Kepala Daerah dipilih secara murni oleh lembaga DPRD tanpa interventi Pemerintah Pusat.

5. Sitem pemilihan langsung (UU Nomor 32 Tahun 2004 jo. UU Nomor 12 Tahun 2008), di mana Kepala Daerah dipilih langsung oleh rakyat.

\footnotetext{
${ }^{19}$ Sarundajang, Pilkada Langsung: Problema dan Prospek, Kata Hasta Pustaka, Jakarta, 2005., hlm. 33
} 
Dalam sistem pemilihan perwakilan semu (UU Nomor 5 Tahun 1974) ditemukan banyak penyimpangan dalam pemilihan kepala daerah, diantara bentukbentuk penyimpangan itu adalah kuatnya intervensi pemerintah Pusat dalam penentuan pejabat Kepala Daerah, seperti disinyalir oleh Syaukani HR, Afan Gaffar dan M.Ryaas Rasyid yang mencatat bahwa rekruitmen politik lokal ditentukan oleh orang Jakarta, khususnya pejabat Depdagri untuk pengisian jabatan Bupati, Walikota, Sekretaris Daerah dan KepalaKepala Dinas di Provinsi. Sementara untuk jabatan Gubernur ditentukan oleh Depdagri, Markas Besar TNI dan Sekretaris Negara. ${ }^{20}$

Sebagai reaksi dari sistem pemilihan perwakilan semu, yang kental dengan intervensi pusat, selanjutnya diganti dengan sistem pemilihan perwakilan yang memberikan otoritas dan wewenang penuh kepada DPRD dalam menentukan kepala daerah. Namun dalam kenyataannya, proses pemilihan Kepala Daerah melalui DPRD di sejumlah daerah terindikasi adanya kasus-kasus money politic, ${ }^{21}$ intervensi pusat, dan distorsi aspirasi publik. Penguatan peran yang dimiliki DPRD, menjadikan institusi

${ }^{20}$ Syaukani HR, Affan Gaffar, dan Ryaas Rasyid, Otonomi Daerah Dalam Negara Kesatuan, Pustaka Pelajar, Yogyakarta, 2004., hlm. 38

${ }^{21}$ Dalam proses pemilihan Kepala Daerah melalui DPRD di seluruh Indonesia, hampir semua berindikasi money politic (politik uang) misalnya; pemilihan gubernur Jawa Timur, Jawa Tengah, Sumatera Selatan, dan Bali. Lihat Juanda, Hukum Pemerintahan Daerah; Pasang Surut Hubungan Kewenangan antara DPRD dan Kepala Daerah, Edisis Kedua, Cetakan Ke-1, Alumni, Bandung, 2008., hlm. 6
DPRD memposisikan diri sebagai 'atasan kepala daerah'. DPRD tidak memposisikan diri sebagai 'mitra penyelenggara pemerintahan daerah'. Pengalaman "buruk" praktik pengisian jabatan Kepala Daerah melalui DPRD tersebut, mendorong untuk dilakukan pemilihan kepala daerah secara langsung, karena beberapa alasan (raison d'etre) yang sangat mendasar, yakni, Pertama, kepala daerah yang terpilih melalui pemilihan langsung akan mendapat mandat dan dukungan yang lebih riil dari rakyat, sebagai wujud kontrak sosial antara pemilih dengan tokoh yang dipilih. Kemauan orang-orang yang memilih (volonte generale) akan menjadi pegangan bagi Kepala Daerah dalam melaksanakan kewenangannya. Kedua, pemilihan Kepala Daerah langsung secara otomatis akan menghindari intrikintrik politik, seperti dalam proses pemilihan dengan sistem perwakilan. Ketiga, pemilihan Kepala Daerah langsung akan memberikan kesempatan yang luas kepada rakyat untuk menentukan pilihannya secara langsung tanpa mewakilkan kepada orang lain. Kecenderungan dalam sistem perwakilan adalah terjadinya penyimpangan antara aspirasi rakyat dengan wakilnya. Ini semakin diperparah oleh dominannya pengaruh partai politik yang telah mengubah fungsi wakil rakyat menjadi wakil partai politik (political party representation). Keempat, pemilihan langsung dapat menciptakan perimbangan antara berbagai kekuatan dalam penyelenggaraan negara terutama dalam menciptakan mekanisme checks and balances antara Kepala Daerah dengan lembaga perwakilan (DPRD) karena sama-sama dipilih oleh rakyat. Kelima, mekanisme 
pemilihan kepala daerah langsung merupakan salah satu bentuk partisipasi aktif rakyat dalam politik dan sebagai manifestasi dari kedaulatan rakyat (demokrasi) serta merupakan bagian esensial bagi penguatan demokrasi (deepening democracy) hingga ke tingkat lokal. ${ }^{22}$

Pemilihan kepala daerah secara langsung di Indonesia dimulai pada tahun 2005, tepatnya pada bulan Juni 2005. Pemilukada langsung di Indonesia sering dikatakan sebagai suatu lompatan demokrasi di tingkat lokal, di mana rakyat di daerah mempunyai kesempatan untuk memilih kepala daerahnya secara langsung melalui mekanisme pemungutan suara. Melalui pemilukada langsung, maka rakyat dapat menentukan jalannya pemerintahan dengan memilih pemimpin yang dikehendaki secara bebas dan rahasia.

\section{Hubungan Antara Kedudukan Gubernur Dengan Sistem Pengisian Jabatan Gubernur.}

Negara Indonesia sebagai Negara Kesatuan secara tegas dimuat dalam ketentuan Pasal 1 ayat (1) UUD Tahun 1945 yang berbunyi "Negara Indonesia ialah Negara Kesatuan...". ${ }^{23}$ UUD NRI Tahun 1945 sebagai landasan konstitusional Negara Kesatuan Republik Indonesia memberi pedoman dasar penyelenggaraan pemerintahan daerah. UUD NRI Tahun 1945

22 Diadaptasi dalam Saldi Isra, Pemilihan Presiden Langsung dan Problematika Koalisi dalam Sistem Presidensial, Jurnal Konstitusi, PUSaKO Universitas Andalas., Vol. II, No. 1, Juni 2009., hlm. 108-109.

${ }^{23}$ Lihat: ketentuan Pasal ayat (1) UUD 1945 berbunyi "Negara Indonesia ialah Negara Kesatuan, yang berbentuk Republik". mengatur bahwa pemerintahan daerah dalam Negara Kesatuan Republik Indonesia dibagi atas dua susunan yakni daerah provinsi dan daerah yang terdapat dalam daerah provinsi yaitu daerah kabupaten dan kota. Ke-dua susunan pemerintahan daerah dimaksud, ditegaskan dalam ketentuan Pasal 18 ayat (1) UUD Tahun 1945 yang berbunyi "Negara Kesatuan Republik Indonesia dibagi atas daerah-daerah Provinsi dan daerah Provinsi dibagi atas Kabupaten dan Kota yang tiap-tiap Provinsi, Kabupaten dan Kota itu mempunyai pemerintahan daerah yang diatur undang-undang".

Dari ketentuan di atas, jelas disebutkan bahwa terdapat dua susunan pemerintahan daerah yakni daerah provinsi dan daerah kabupaten dan kota. Susunan pemerintahan daerah dengan model seperti ini, lazim dikenal dalam praktik pemerintahan di berbagai negara, yakni pemerintahan subnasional dibedakan atas Unit Dasar (basic unit) dan Unit Antara (intermediate unit). ${ }^{24}$ Selain itu, disebutkan juga institusi pemerintahan daerah yang diatur dalam ketentuan Pasal 18 ayat (3) UUD 1945 berbunyi "Pemerintahan daerah provinsi, daerah kabupaten, dan kota memiliki Dewan Perwakilan Rakyat Daerah yang anggota-anggotanya dipilih melalui pemilihan umum". Selanjutnya ketentuan Pasal 18 ayat (4) UUD 1945 menyebutkan bahwa "Gubernur, Bupati, dan Walikota masing-masing sebagai kepala pemerintah daerah provinsi,

24 Lihat: Kementerian Dalam Negeri RI, Bahan Diseminasi Pokok-Pokok Revisi Penyempurnaan Pengaturan Pemilihan Kepala Daerah, 2010., hlm. 63 
kabupaten dan kota dipilih secara demokratis".

UUD NRI Tahun 1945 yang secara eksplisit menyebut jabatan Gubernur sebagai kepala pemerintah daerah provinsi, dimuat dalam rumusan Pasal 18 ayat (4) UUD NRI Tahun 1945 yang berbunyi: "Gubernur...sebagai kepala pemerintah daerah provinsi...dipilih secara

demokratis". ${ }^{25}$ Lembaga/institusi

DPRD juga disebut secara eksplisit dalam Pasal 18 ayat (3) UUD 1945 dengan rumusan kalimat, "Pemerintahan daerah provinsi...memiliki Dewan Perwakilan Rakyat Daerah yang anggota-anggotanya dipilih melalui pemilihan umum". ${ }^{26}$ Atas dasar ketentuan ini, maka di setiap pemerintahan daerah provinsi terdapat Dewan Perwakilan Rakyat Daerah provinsi yang bersama-sama dengan Gubernur merupakan satu kesatuan pengertian pemerintahan daerah. $^{27}$ Akan tetapi, kedudukan dan kewenangan baik Gubernur ataupun DPRD provinsi sama sekali tidak diatur dalam UUD $1945 .^{28}$ Artinya, organ konstitusi yang kewenangannya diberikan oleh UUD 1945 bukanlah Gubernur atau DPRD provinsi secara sendiri-sendiri,

${ }^{25}$ Lihat: Pasal 18 ayat (4) UUD NRI Tahun 1945 berbunyi: "Gubernur, Bupati dan Walikota, masing-masing sebagai kepala pemerintah provinsi, kabupaten, dan kota dipilih secara demokratis".

26 Lihat Pasal 18 ayat (3) UUD 1945 berbunyi, "Pemerintahan daerah provinsi, daerah kabupaten, dan kota memiliki Dewan Perwakilan Rakyat Daerah yang anggotaanggotanya dipilih melalui pemilihan umum".

27 Jimly Asshidiqie, Perkembangan dan Konsolidasi Lembaga-Lembaga Negara Pasca Reformasi, Konstitusi Press, Jakarta, 2006., hlm. 280-281.

${ }^{28}$ Ibid., hlm. 282 melainkan pemerintahan daerah provinsi sebagai satu kesatuan institusi. $^{29}$ Ini berarti, organ yang diberikan kewenangan konstitusional oleh UUD 1945 adalah pemerintahan daerah provinsi. Namun demikian, Gubernur dan DPRD provinsi secara sendiri-sendiri dapat saja disebut sebagai organ konstitusi, mengingat ke-duanya (Gubernur dan DPRD Provinsi) secara eksplisit disebut juga dalam UUD $1945 .{ }^{30}$ Tetapi dalam konteks pengertian lembaga negara yang kewenangannya diberikan oleh UUD, maka yang mempunyai status konstitusional yang bersifat langsung adalah pemerintahan daerah provinsi, sedangkan Gubernur dan DPRD provinsi secara sendiri-sendiri hanya dapat ditafsirkan memiliki kewenangan konstitusional yang bersumber dari pemberian UUD 1945 secara tidak langsung. ${ }^{31}$

Namun demikian, pemerintahan daerah provinsi merupakan satu kesatuan yakni antara Gubernur dan DPRD provinsi. Dengan kata lain, Gubernur dan DPRD provinsi adalah sebagai organ pemerintahan daerah provinsi yang utama. Ketentuan Pasal 18 ayat (2) merumuskan bahwa "Pemerintahan daerah provinsi...mengatur dan mengurus sendiri urusan pemerintahan menurut asas otonomi dan tugas pembantuan. ${ }^{32}$ Ketentuan Pasal 18 ayat (5) berbunyi "Pemerintahan daerah menjalankan otonomi seluas-luasnya, kecuali urusan pemerintahan yang oleh

\footnotetext{
${ }^{29}$ Ibid., hlm. 283.

${ }^{30}$ Ibid.

${ }^{31}$ Ibid.

${ }^{32}$ Pasal 18 ayat (2) UUD 1945 berbunyi, "Pemerintahan daerah provinsi, daerah kabupaten, dan kota mengatur dan mengurus sendiri urusan pemerintahan menurut asas otonomi dan tugas pembantuan".
} 
undang-undang ditentukan sebagai urusan Pemerintah Pusat. Di samping itu, Pasal 18 ayat (6) juga mengatur bahwa "pemerintahan daerah berhak menetapkan peraturan daerah dan peraturanperaturan lain untuk melaksanakan otonomi dan tugas pembantuan".

Berdasarkan ketentuan

tersebut di atas, pemerintahan daerah sebagai satuan pemerintahan mandiri di daerah merupakan penyelenggara pemerintahan daerah otonom. Gubernur, Bupati, Walikota sebagai penyelenggara otonomi di daerah. Hal ini berarti, dalam sistematika pemerintahan daerah tidak ada lagi unsur pemerintahan sentralisasi. ${ }^{33}$ Satuan pemerintahan dekonsentrasi sebagai unsur pemerintahan pusat (sentralisasi) di daerah tidak diatur dalam rumusan ketentuan Pasal 18 UUD 1945.

Meskipun demikian, menurut Bagir Manan tidak berarti pembentukan satuan pemerintahan dekonsentrasi di daerah menjadi terlarang. ${ }^{34}$ Satuan pemerintahan dekonsentrasi walaupun tidak diatur dalam ketentuan Pasal 18 UUD 1945, tidak berarti mengandung arti bahwa dekonsentrasi adalah sesuatu yang tidak perlu atau kurang penting. ${ }^{35}$ Dekonsentrasi adalah mekanisme untuk menyelenggarakan urusan pusat yang dilakukan oleh pejabat Pusat di daerah. ${ }^{36}$ Oleh sebab itu, satuan pemerintahan pusat yang menyelenggarakan urusan pemerintahan tertentu di daerah

\footnotetext{
33 Bagir Manan, Menyongsong Fajar Otonomi Daerah, Pusat Studi UII, Yogyakarta, 2005., hlm. 8

${ }^{34}$ Ibid.

${ }^{35}$ Bagir Manan, Perjalanan Historis Pasal 18 UUD, Unsika, Karawang, 1993., hlm. 52

${ }^{36}$ Ibid.
}

dapat membentuk satuan pemerintahannya di daerah.

Mengingat Negara Republik Indonesia adalah Negara Kesatuan, maka sebagai konsekwensi dari prinsip Negara Kesatuan yang tidak dimungkinkan semua wewenang Pemerintah didesentralisasikan dan diotonomkan sekalipun kepada Daerah. Oleh sebab itu, pembentukan satuan pemerintahan dekonsentrasi, dapat saja diatur dalam undang-undang tentang Pemerintahan Daerah.

UUD NRI Tahun 1945 memberikan kewenangan kepada pembentuk undang-undang untuk mengatur lebih lanjut mengenai penyelenggaraan pemerintahan daerah. Seperti disebutkan dalam ketentuan Pasal 18 ayat (7) bahwa: "Susunan dan tata cara penyelenggaraan pemerintahan daerah diatur dalam undangundang". Demikian halnya ketentuan Pasal 18 ayat (1) UUD 1945 menyatakan bahwa "Negara Kesatuan Republik Indonesia dibagi atas daerah-daerah Provinsi...yang mempunyai pemerintahan daerah diatur dengan undang-undang". 37

UU Nomor 32 Tahun 2004 tentang Pemerintahan Daerah sebagai penjabaran lebih lanjut ketentuan Pasal 18 UUD NRI Tahun 1945, selain mengatur asas desentralisasi dan tugas pembantuan, juga mengatur asas dekonsentrasi. Ketentuan Pasal 20 ayat (2) menyebutkan bahwa "Dalam menyelenggarakan pemerintahan,

\footnotetext{
37 Pasal 18 ayat (1) UUD 1945 berbunyi "Negara Kesatuan Republik Indonesia dibagi atas daerah-daerah Provinsi dan daerah Provinsi dibagi atas Kabupaten dan Kota yang tiap-tiap Provinsi, Kabupaten dan Kota itu mempunyai pemerintahan daerah yang diatur undang-undang”.
} 
Pemerintah menggunakan asas desentralisasi, tugas pembantuan dan dekonsentrasi sesuai peraturan perundang-undangan". Sedangkan dalam Pasal 20 ayat (3) menyebutkan bahwa "Dalam menyelenggarakan pemerintahan daerah, Pemerintah Daerah menggunakan asas otonomi dan tugas pembantuan". Dari ketentuan ini, jelas dibedakan penggunaan asas penyelenggaraan pemerintahan antara Pemerintah dan Pemerintah Daerah. Asas desentralisasi, tugas pembantuan dan dekonsentrasi merupakan asas penyelenggaraan pemerintahan yang digunakan oleh Pemerintah dalam menyelenggarakan urusan pemerintahan. Namun untuk pemerintahan daerah ditentukan hanya menggunakan asas otonomi dan tugas pembantuan.

Dari pembedaan asas penyelenggaraan pemerintahan yang digunakan oleh Pemerintah dan Pemerintah Daerah tersebut, mengidikasikan adanya perbedaan jangkauan urusan pemerintahan yang akan diurus dan diselenggarakan masing-masing tingkat/susunan pemerintahan antara Pemerintah dan Pemerintahan Daerah, sekaligus menegaskan hubungan yang bersifat hierarkis dan vertikal antara susunan/tingkat pemerintahan yakni antara Pemerintah dan Pemerintahan Daerah provinsi, daerah kabupaten dan kota. $^{38}$ Hubungan hierarkis tersebut, merupakan konsekwensi logis sebagai negara kesatuan yang menganut prinsip desentralisasi yang tidak mengenal adanya "negara di dalam negara". Sebab, desentralisasi itu bermakna "hierarki", yakni

${ }^{38}$ Lihat, Jimly Asshidiqie, Konsolidasi Naskah UUD 1945 Setelah Perubahan Keempat, Pusat Studi Hukum Tata Negara UI, Jakarta, 2002., hlm. 21 sebuah piramid tingkatan-tingkatan pemerintahan dengan degradasi kekuasaan yang mengalir dari atas ke bawah. $^{39}$

Pemerintah menggunakan asas desentralisasi sebagai instrumen pemencaran kekuasaan (spreiding van machten) berupa penyerahan wewenang pemerintahan oleh Pemerintah kepada daerah-daerah otonom untuk mengatur dan mengurus urusan rumah tangga pemerintahannya sendiri. Dekonsentrasi dan tugas pembantuan diselenggarakan karena tidak semua wewenang pemerintahan dapat dilakukan dengan menggunakan asas desentralisasi. Oleh sebab itu, demi efisiensi dan efektivitas penyelenggaraan pemerintahan digunakan asas dekonsentrasi dan tugas pembantuan.

Dekonsentrasi sebagai instrumen (sentralisasi) diwujudkan dalam jabatan Gubernur sebagai Wakil Pemerintah, seperti disebutkan dalam ketentuan Pasal 1 angka 8 UU Nomor 32 Tahun 2004 tentang Pemerintahan Daerah bahwa "Dekonsentrasi adalah pelimpahan wewenang pemerintahan oleh Pemerintah kepada Gubernur sebagai Wakil Pemerintah...".40 Konstruksi perwilayahan yang dianut dalam Undang-Undang Nomor 32 Tahun 2004, menempatkan Provinsi sebagai daerah otonom, sekaligus menempatkan Gubernur sebagai wakil Pemerintah. Oleh sebab itu, Gubernur memiliki status ganda

\footnotetext{
${ }^{39}$ Elazar, Daniel J., American Federalism: A View from the State. $3^{\text {rd }}$ Edition. New York: Harper \& Row, Publisher, 1984., hlm. 7

40 Lihat : Pasal 1 angka 8 berbunyi: "Dekonsentrasi adalah pelimpahan wewenang Pemerintahan oleh Pemerintah kepada Gubernur sebagai wakil Pemerintah dan/atau instansi vertikal di wilayah tertentu".
} 
yakni sebagai kepala pemerintah daerah provinsi (daerah otonom) dan sebagai wakil Pemerintah yang melaksanakan tugas-tugas dekonsentrasi di wilayah provinsi.

Kedudukan Gubernur yang mengemban "dual function" sebagai Kepala Daerah otonom dan wakil Pemerintah, memberi penegasan perlunya memahami substansi dari sistem dan prosedur pengisian jabatan Gubernur. Untuk memahami secara komprehensif substansi dan proses pemilihan kepala daerah dalam konteks keberadaan suatu daerah otonom. Pertama, dalam wadah negara kesatuan, daerah otonom adalah bentukan dari Pemerintahan Nasional, daerah otonom adalah bagian integral Pemerintahan Nasional. Oleh sebab itu, hubungan antara Pemerintah Nasional dan Pemerintah Daerah adalah bersifat hierarkis. Kedua, Pemerintah Daerah, atau umumnya disebut pemerintahan sub-nasional, dapat terdiri atas satu atau lebih susunan/tingkatan. Lazimnya dalam praktik pemerintahan di berbagai negara, pemerintahan sub-nasional dibedakan atas Unit Dasar (basic unit) dan Unit Antara (intermediate unit). ${ }^{41}$ Fungsi utama Unit Dasar adalah menyediakan pelayanan kepada masyarakat, sedangkan fungsi utama Unit Antara adalah menjamin terwujudnya kemampuan Unit Dasar untuk melaksanakan fungsinya. Jaminan tersebut dilakukan melalui kegiatan koordinasi, pembinaan dan pengawasan. $^{42}$ Oleh sebab itu, dengan merujuk pada perbedaan fungsi antara kedua susunan/tingkatan Pemerintahan sub-

41 Lihat: Kementerian Dalam Negeri RI, Bahan Diseminasi ...Loc.Cit.

${ }^{42}$ Ibid. nasional tersebut, mengindikasikan prasyarat yang juga berbeda untuk rekruitmen pemimpinnya.

Dalam kaitan ini, penerapan mekanisme pemilihan secara langsung untuk Gubernur dan Bupati/Walikota tidak berarti mesti "persyaratan" pengisian jabatannya harus sama. Kedudukan yang diemban oleh Gubernur sebagai kepala pemerintah daerah provinsi di satu sisi dan sebagai wakil pemerintah di sisi lainnya, selayaknya tercermin dalam pengisian jabatan Gubernur.

\section{Pengisian Jabatan Gubernur : Suatu Alternatif Solusi.}

Dalam konteks kedudukan Gubernur, UU Nomor 32 Tahun 2004 pada prinsipnya menganut paradigma yang sama dengan UU Nomor 22 Tahun 1999, Gubernur diposisikan sebagai Kepala Daerah dan sebagai Wakil Pemerintah. Posisi Gubernur yang mengemban "dual function" ini, dikenal dengan istilah "fused model". Artinya pemerintah menempatkan Gubernur, selain sebagai Kepala Daerah otonom juga menjadi wakil pemerintah pusat. Berbeda dengan kabupaten dan kota diberlakukan "split model", yang artinya bupati/ walikota hanya berkedudukan sebagai Kepala Daerah otonom. ${ }^{43}$ Karena itu, posisi pemerintah provinsi dalam koridor otonomi daerah memiliki 2 (dua) kedudukan, yakni sebagai wakil pemerintah pusat dengan menjadikan aparat dekonsentrasi, dan sekaligus juga menjadi pelaksana otonomi daerah atau aparat desentralisasi. Sementara Kabupaten/Kota tidak lagi

${ }^{43}$ Ibid. 
memiliki fungsi yang inheren dengan fungsi dekonsentrasi.

Namun, perbedaan yang cukup mendasar yakni pada pemilihan Kepala Daerah yang sebelumnya dipilih oleh DPRD (UU Nomor 22 Tahun 1999), kemudian diganti dengan model pemilihan secara langsung (UU Nomor 32 Tahun 2004). Pelaksanaan pemilihan kepala daerah secara langsung dilatarbelakangi oleh berbagai keinginan mewujudkan sebuah sistem pemilihan kepala daerah yang lebih demokratis dan sensitif terhadap aspirasi rakyat di daerah.

Menurut Saldi Isra, apabila frasa pemilihan secara demokratis dimaknai menjadi pemilihan secara langsung, salah satu basis argumentasinya adalah penyeragaman model pemilihan, sebagaimana praktik dalam sistem presidensial, pemimpin eksekutif tertinggi dipilih secara langsung. Namun, jika usul Gubernur dipilih DPRD diterima, akan ada dua masalah serius dalam konteks sistem pemerintahan, yaitu : pertama, Gubernur akan hadir dalam legitimasi yang berbeda dibanding Bupati dan/atau Walikota. Bagaimanapun, bila gubernur dipilih DPRD, sementara bupati dan/atau walikota dipilih langsung, maka gubernur potensial kesulitan berhadapan dengan bupati dan/atau walikota. kedua, Gubernur akan berhadapan dengan legitimasi DPRD yang dipilih langsung dari rakyat. Jika salah satunya dipilih langsung oleh rakyat, dapat dipastikan bahwa yang tidak mendapat mandat langsung dari rakyat akan dengan mudah berada di bawah tekanan. ${ }^{44}$

\footnotetext{
${ }^{44}$ Saldi Isra, Loc. Cit.
}

Selain itu, ketentuan Pasal 18 UUD 1945 secara eksplisit menyatakan bahwa Gubernur, seperti halnya Bupati dan Walikota, berkedudukan sebagai kepala daerah otonom. Hal itu berarti, sistem pemilihan bagi Gubernur harus berlaku sama dengan sistem pemilihan Bupati dan Walikota. Melalui pemilukada langsung, para Gubernur, Bupati dan Walikota selaku kepala daerah otonom memperoleh mandat politik secara langsung dari rakyat. Di sisi lain, tidak satu pun pasal atau ayat dalam UUD 1945 yang menyatakan bahwa Gubernur adalah wakil pemerintah pusat di daerah. Gubernur sebagai wakil pemerintah pusat diatur dalam UU Nomor 32 Tahun 2004 tentang Pemerintahan Daerah. Oleh sebab itu, wacana perubahan sistem pemilihan Gubernur, semestinya dirangkaikan dengan pemikiran tentang perlunya amandemen kembali Pasal 18, 18A, dan 18B UUD $1945 .^{45}$

Sehubungan dengan hal tersebut, Kajung Marijan menilai bahwa wacana pemilihan gubernur oleh DPRD bukan solusi untuk menyelesaikan berbagai dampak yang timbul akibat pemilihan langsung. Persoalan utama pemilihan gubernur secara langsung menyangkut efisiensi. Oleh sebab itu, mestinya dibuat sistem yang lebih sederhana, misalnya gubernur dipilih secara langsung, tetapi dibuat hanya berlangsung satu putaran. Calon yang meraih suara terbanyak otomatis yang terpilih. ${ }^{46}$ Cara lain adalah mengadopsi sistem preferensi

45 Lihat: Syamsuddin Haris, Memperkuat Peran Gubernur, "Opini", harian Kompas, 26 November 2010.

46 Lihat, harian Media Indonesia, 01 Februari 2011. 
seperti di Australia. Sistem preferensi, bisa memunculkan kepala daerah yang dipilih secara mayoritas. Dengan sistem ini, kepala daerah dapat terpilih hanya dalam satu putaran, tetapi tetap legitimate karena dipilih oleh mayoritas. Pasalnya, pemilihan dilakukan dengan cara memberikan peringkat kepada tiap-tiap calon kepala daerah. Misalnya, ada 4 (empat) calon, pemilih tinggal menandai calon yang paling disukai atau rangking 1 sampai 4. Setelah itu, baru dilakukan penghitungan, calon yang memperoleh suara mayoritas otomatis terpilih. ${ }^{47}$ Selain alternatif pemilukada satu putaran tersebut, perlu dipikirkan alternatif lain berupa penataan ulang ke arah 2 (dua) momentum pemilihan umum saja dalam setiap lima tahun, yakni pemilu nasional (memilih presiden/wakil presiden, DPR dan DPD); dan pemilu lokal (memilih Kepala Daerah dan DPRD).

Penyempurnaan pengaturan pemilihan Gubernur pada akhirnya akan berujung pada persoalan memilih alternatif desain pengaturan yang dianggap tepat. Dari pendekatan historis, memperlihatkan bahwa praktek pengisian jabatan Kepala Daerah melalui mekanisme pemilihan semu sebagaimana dipraktekkan pada masa berlakunya UU Nomor 5 Tahun 1974, menciptakan dominasi pemerintah pusat terhadap pemerintah daerah. Pemerintah pusat dalam banyak hal, berusaha mengontrol daerah melalui figur Kepala Daerah yang diposisikan sebagai alat pusat dan alat daerah. Untuk memenangkan kesetiaan Kepala Daerah kepada pusat dalam menjalankan "dual

${ }^{47}$ Lihat, harian Kompas, 8 Pebruari 2011. function"nya tersebut, Pemerintah Pusat seringkali sangat dominan dalam penentuan/pengangkatan Kepala Daerah. Kuatnya bargaining position pusat dalam penentuan Kepala Daerah ini telah mendorong loyalitas Kepala Daerah yang lebih tinggi kepada Pusat dibandingkan kepada Daerah.

Berbagai aspek positip dari kebijaksanaan ini adalah adanya kepastian bahwa program-program ataupun arahan pusat akan terlaksana secara lancar di daerah. Pada tahap awal kemerdekaan pendekatan ini sangat berguna untuk menggalang persatuan dan kesatuan bangsa yang masih sangat rawan pada waktu itu (tujuan integratif). Aspek negatipnya, terutama setelah tujuan integratif tercapai adalah pada diri Kepala Daerah sendiri, yang akan sering dihadapkan pada suatu dilema manakala dihadapkan pada situasi harus memilih antara kepentingan pusat dan daerah. Ke-Pusat dia dituntut akan loyalitas, ke daerah dia dihadapkan pada akuntabilitas.

Keadaan tersebut di atas, berakhir setelah memasuki era Reformasi. Pada era reformasi, pengaturan tentang Pemilihan Kepala Daerah telah terjadi 2 (dua) kali. pertama, pada saat ditetapkannya UU Nomor 22 Tahun 1999 tentang Pemerintahan Daerah yang mengatur bahwa Pemilihan Kepala Daerah dilakukan dengan sistem perwakilan (DPRD). Praktek pemilihan Kepala Daerah oleh DPRD, merupakan sejarah baru dalam penyelenggaraan pemerintahan daerah. Praktek ini, semakin meningkatkan taraf pembangunan nilai-nilai demokrasi dalam kehidupan masyarakat dan pemerintahan. Sebelum berlakunya UU Nomor 22 Tahun 1999, mekanisme pemilihan kepala daerah 
oleh DPRD, hanya sekedar formalitas belaka. Kepala Daerah selalu ditentukan oleh Presiden atau pejabat yang ditunjuknya.

Namun perkembangan lebih lanjut dari pemilihan kepala daerah oleh DPRD memunculkan banyak kontroversi terutama praktik politik uang (money politics), dan "DPRD yang kebablasan". Penguatan peran yang dimiliki DPRD, menjadikan institusi DPRD memposisikan diri sebagai "atasan kepala daerah". DPRD tidak mencerminkan semangat sebagai "mitra penyelenggara pemerintahan daerah" dari Kepala Daerah. Berbagai penyimpangan semangat penyelenggaraan pemerintahan daerah tersebut, kemudian diakomodir dalam UU Tentang Pemerintahan yang baru, yaitu UU Nomor 32 Tahun 2004 yang merubah sistem pemilihan Kepala Daerah dari pemilihan oleh DPRD, menjadi dipilih langsung oleh rakyat di daerah yang bersangkutan.

$$
\text { Penerapan mekanisme }
$$

pemilihan Kepala Daerah secara langsung, jelas memiliki derajat legitimasi yang lebih tinggi dibandingkan melalui perwakilan (DPRD). Oleh karena itu, adanya pemikiran dan upaya untuk mengembalikan mekanisme Pemilihan Kepala Daerah secara langsung oleh rakyat, kepada pemilihan oleh DPRD, jelas merupakan suatu kemunduran yang nyata dari praktik demokrasi. Padahal salah satu ruh tuntutan reformasi politik yang berlangsung sejak tahun 1998 yang lalu, adalah memberikan hak kepada rakyat untuk dapat menentukan (memilih) pemimpinya secara langsung dari tingkat pusat hingga tingkat daerah.
Namun, dalam konteks pengisian jabatan Gubernur, dapat saja dipertimbangankan bahwa Gubernur mengemban "dual function”, maka persyaratan pemilihannya tidak mesti sama dengan pemilihan Bupati/Walikota. Oleh sebab itu, perlu dipertimbangkan suatu model kombinasi antara model pemilihan dan pengangkatan, sehingga dapat memenuhi kedua fungsi Gubernur tersebut. Seperti digambarkan pada bagan 1 .

Bagan di atas, menunjukkan bahwa kedudukan Gubernur adalah sebagai kepala daerah otonom dan wakil pemerintah. Gubernur dalam kedudukannya sebagai kepala daerah otonom yang dipilih langsung oleh rakyat, berarti mempunyai legitimasi yang lebih kuat dari pada pemilihan yang lainnya dan juga memperkuat posisi gubernur sebagai kepala daerah otonom, sehingga ekspektasi rakyat atas keterlibatannya secara langsung dalam penentuan Gubernur menjadi dasar bagi rakyat untuk selalu mengawasi pelaksanaan tugas, fungsi dan wewenang Gubernur dalam penyelenggaraan urusan pemerintahan daerah. Sedangkan Gubernur sebagai wakil Pemerintah Pusat, berarti melaksanakan tugastugas yang dilimpahkan kepada Gubernur sebagai pejabat pusat di daerah. Gubernur dalam melaksanakan tugasnya sebagai wakil Pemerintah Pusat senantiasa berada dalam pengawasan dan bertanggungjawab kepada Pemerintah Pusat. Oleh karena itu, dalam pengisian jabatan Gubernur, Pemerintah Pusat semestinya juga mempunyai peranan dalam memastikan Gubernur yang akan dipilih oleh rakyat mempunyai kapabilitas untuk melakukan tugas- 
tugas sebagai wakil Pemerintah di wilayah provinsi.

\section{Bagan 1}

Model Sistem Pengisian Jabatan Gubernur

(Suatu Alternatif)

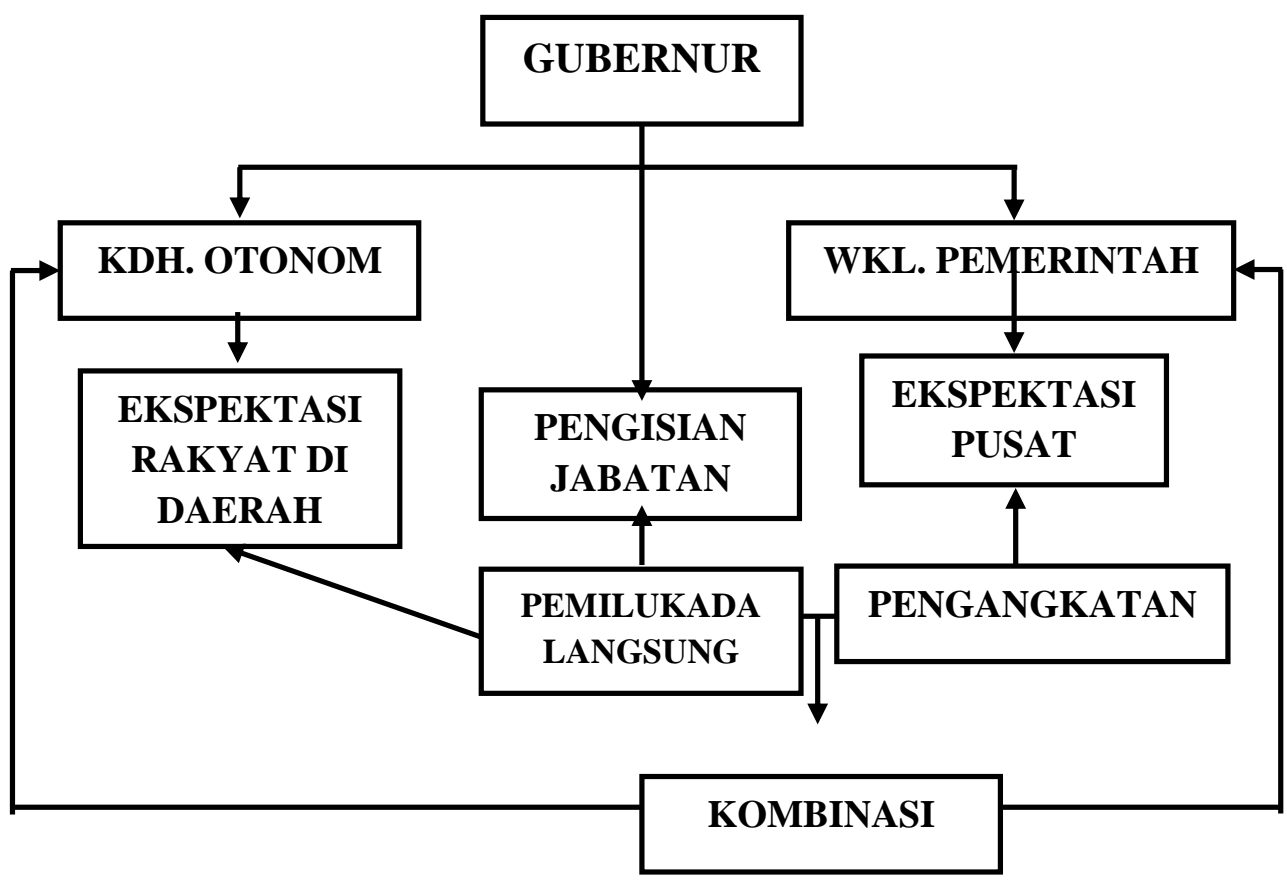

Peranan pemerintah pusat dimaksud, tidak dalam kerangka mendiskualifikasi (menggugurkan) calon-calon Gubernur, tetapi sekedar memberi pertimbangan berupa penilaian terhadap kapasitas masingmasing calon Gubernur yang akan dipilih oleh rakyat secara langsung. Mekanisme seperti itu dapat mengadopsi model debat kandidat pada proses pemilihan Presiden dan Wakil Presiden. Masing-masing calon Gubernur diberi penilaian yang dilakukan oleh Tim Independen yang keanggotaannya terdiri dari unsur pemerintah, akademisi dan organisasi profesi lainnya yang mempunyai kapasitas dan kompetensi untuk melakukan penilaian terhadap calon-calon Gubernur.
Dari penilaian yang dilakukan oleh Tim Independen bentukan Pemerintah tersebut, selanjutnya masing-masing calon Gubernur dimaksud, setelah dilakukan penilaian oleh Tim Independen, kemudian diumumkan melalui media cetak dan elektronik nasional dan lokal beserta skor penilaiannya. Hal ini dilakukan dalam kerangka memberi preferensi kepada rakyat di daerah yang bersangkutan, untuk menentukan pilihannya terhadap kualitas dan kapabilitas masingmasing calon Gubernur yang akan bersaing dalam pemilihan Gubernur. Sekaligus sebagai bentuk tanggung jawab pemerintah dalam memberi penilaian terhadap kualitas dan kapasitas calon Gubernur, yang apabila kelak terpilih dapat 
mengemban fungsinya dengan baik, sebagai Kepala Daerah Otonom, sekaligus sebagai Wakil Pemerintah di daerah.

Sehubungan dengan hal tersebut, dapat dirumuskan mekanisme pengisian jabatan Gubernur yang dapat memenuhi kedua unsur dari kedudukan gubernur, yakni gubernur tetap dipilih secara langsung, namun dalam persyaratan pencalonan gubernur ditambahkan persyaratan berupa "mendapat pertimbangan Presiden" sebelum ditetapkan sebagai calon yang akan dipilih oleh rakyat secara langsung di daerah yang bersangkutan. Pemenuhan terhadap persyaratan tersebut dapat berupa langkah-langkah sebagai berikut: ${ }^{48}$

a. KPU Provinsi melakukan pendaftaran calon sesuai dengan ketentuan yang berlaku;

b. Bakal calon yang terdaftar diajukan oleh KPU Provinsi kepada Pemerintah Pusat untuk diberi pertimbangan;

c. Untuk memberikan pertimbangan, Pemerintah Pusat membentuk tim independen yang keanggotaannya terdiri dari unsur-unsur pemerintah, dan organisasi profesi. Hasil pertimbangan Pemerintah dapat berupa kualifikasi bakal calon;

d. Bakal calon yang "qualified" disampaikan kepada KPU Provinsi untuk ditetapkan sebagai

48 Lihat: Bahan Diseminasi Pokok-Pokok Revisi Penyempurnaan Pengaturan Pemilihan Kepala Daerah...Op.Cit., hlm. 68 calon Gubernur, dan kemudian proses pemilihan secara langsung.

e. Calon dengan suara terbanyak (hasil pemilihan) oleh KPU provinsi disampaikan kepada Presiden untuk disahkan.

Model pengisian jabatan Gubernur seperti tersebut di atas, mengadopsi model pengisian jabatan Gubernur yang dianut dalam UU Nomor 22 Tahun 1999. Meskipun Gubernur dipilih oleh DPRD Provinsi, tetapi sebelum ditetapkan sebagai calon Gubernur yang akan dipilih DPRD, terlebih dahulu "dikonsultasikan" kepada Presiden. Mekanisme ini berbeda dengan pengisian jabatan Bupati/Walikota yang tidak mensyaratkan adanya "konsultasi" kepada Pemerintah. Tetapi bakal calon Bupati/Walikota yang telah memenuhi syarat, otomatis ditetapkan sebagai calon yang akan dipilih oleh DPRD kabupaten/kota. Pembedaan mekanisme pengisian jabatan Gubernur dengan Bupati/Walikota dalam UU Nomor 22 Tahun 1999 mengindikasikan peran dan fungsi yang diemban berbeda, sehingga mekanisme pengisian jabatannya juga dibedakan. Dalam UU Nomor 22 Tahun 1999, Gubernur selain sebagai Kepala Daerah otonom juga sebagai wakil Pemerintah di daerah, sedangkan Bupati/Walikota sematamata sebagai Kepala Daerah yang menyelenggarakan urusan pemerintahan otonomi dan tugas pembantuan. Model pengisian jabatan Gubernur sebagaimana dianut dalam UU Nomor 22 Tahun 1999 tersebut, mestinya diadopsi 
dalam pengisian jabatan Gubernur, meskipun dengan mekanisme pemihan langsung oleh rakyat. Hal ini merupakan implikasi dan konsekuensi logis dari kedudukan Gubernur yang mengembang "dual function" sebagai Kepala Daerah dan sebagai wakil Pemerintah di Daerah.

\section{Penutup}

\subsection{Kesimpulan}

Dari uraian di atas, dapat disimpulkan bahwa: pertama, Gubernur dalam kedudukannya sebagai kepala daerah otonom dipilih langsung oleh rakyat, yang berarti mempunyai legitimasi lebih kuat dari pada model pemilihan yang lainnya (melalui DPRD), sehingga ekspektasi rakyat atas keterlibatannya secara langsung dalam pemilihan Gubernur menjadi dasar bagi rakyat untuk selalu mengawasi pelaksanaan tugas, fungsi dan wewenang Gubernur dalam penyelenggaraan urusan pemerintahan daerah. Sedangkan Gubernur sebagai wakil Pemerintah, berarti melaksanakan tugas-tugas yang dilimpahkan kepada Gubernur sebagai pejabat pusat di daerah. Gubernur dalam melaksanakan tugasnya sebagai wakil Pemerintah Pusat senantiasa berada dalam pengawasan dan bertanggungjawab kepada Pemerintah Pusat. Oleh sebab itu, dalam pengisian jabatan Gubernur, Pemerintah Pusat sejatinya juga mempunyai peranan dalam memastikan Gubernur yang akan dipilih oleh rakyat mempunyai kapabilitas untuk melakukan tugastugas sebagai wakil Pemerintah di wilayah provinsi. Karena itu, model pengisian jabatan Gubernur merupakan kombinasi antara pemilihan langsung dengan model pengangkatan semu. Kedua, Pemilihan Gubernur secara langsung adalah model pengisian jabatan Gubernur yang tepat guna membentuk keseimbangan dan kontrol atas kedudukan gubernur sebagai pejabat pusat pada satu sisi dan sebagai pejabat derah otonom pada sisi lainnya. Pemilihan Gubernur secara langsung, setidaknya akan membentuk kemandirian berhadapan dengan Pemerintah Pusat, mengingat kedudukan Gubernur sebagai pejabat daerah otonom yang dipilih secara langsung oleh rakyat. Selain itu, Pemilihan Gubernur secara langsung juga dapat menciptakan perimbangan antara berbagai kekuatan dalam penyelenggaraan negara terutama dalam menciptakan mekanisme checks and balances antara Kepala Daerah dengan lembaga perwakilan (DPRD) karena sama-sama dipilih oleh rakyat.

\subsection{Saran}

Berdasarkan kesimpulan
tersebut, disarankan bahwa
mengingat stutus Gubernur yang
mengemban "dual function", selain
sebagai Kepala Daerah Otonom,
Gubernur juga sebagai Wakil
Gubernur juga sebagai Wakil Pemerintah, maka persyaratan rekruitmen pengisian jabatan Gubernur, selayaknya memberi ruang bagi Pemerintah Pusat untuk terlibat dalam proses pengisian jabatan Gubernur, khususnya dalam tahap "proses pencalonan". Untuk itu, diperlukan suatu perubahan regulasi berupa penyisipan pasal atau ayat pada butir-butir kriteria persyaratan pemilihan Gubernur yakni "mendapat pertimbangan Presiden" sebelum ditetapkan sebagai calon Gubernur, yang akan 
dipilih langsung oleh rakyak di daerah yang bersangkutan. Presiden selaku kepala pemerintahan berhak menentukan pejabat yang kompeten mewakilinya di daerah agar berbagai program pembangunan bisa efektif diimplementasikan di daerah.

\section{DAFTAR PUSTAKA}

\section{Buku.}

Bagir Manan, Perjalanan Historis Pasal 18 UUD 1945, Unsika, Karawang, 1993.

, Menyongsong Fajar

Otonomi Daerah, Cetakan Ke

IV, Pusat Studi UII,

Yogyakarta, 2005.

Elazar, Daniel J., American Federalism: A View from the State. $3^{\text {rd }}$ Edition. New York: Harper \& Row, Publisher, 1984.

Jazim Hamidi dan Mustafa Lutfi, Rethinking Penyelenggaraan Pilkada yang Demokratis dan Partisipatif, dalam Konstitusionalisme

Demokrasi (Sebuah

Diskursus tentang Pemilu,

Otonomi Daerah dan

Mahkamah Konstitusi sebagai Kado untuk 'Sang Penggembala' Prof. A.Mukthie Fadjar, SH., MS.), In-TRANS Publishing, Malang, 2010.

Joko J. Prihatmoko, Pemilihan Kepala Daerah Langsung, Filosofi, Sistem dan Problema, Pustaka Pelajar, Yogyakarta, 2005.

Mendemokratiskan Pemilu; dari Sistem sampai
Elemen Teknis, Pustaka Pelajar, Yogyakarta, 2008.

Juanda, Hukum Pemerintahan Daerah; Pasang Surut Hubungan Kewenangan antara DPRD dan Kepala Daerah, Edisis Kedua, Cetakan Ke-1, Alumni, Bandung, 2008.

Jimly Asshidiqie, Konsolidasi Naskah UUD 1945 Setelah Perubahan Keempat, Pusat Studi Hukum Tata Negara UI, Jakarta, 2002.

Konsolidasi rembangan dan
Lembaga Negara Pasca
Reformasi, Konstitusi Press,
Jakarta, 2006.

Kementerian Dalam Negeri RI, Bahan Diseminasi PokokPokok Revisi Penyempurnaan Pengaturan Pemilihan Kepala Daerah, 2010.

Saldi Isra, Pemilihan Presiden Langsung dan Problematika Koalisi dalam Sistem Presidensial, Jurnal Konstitusi, PUSaKO Universitas Andalas., Vol. II, No. 1, Juni 2009.

Sarundajang, Pilkada Langsung: Problema dan Prospek, Kata Hasta Pustaka, Jakarta, 2005.

Syaukani HR, Affan Gaffar, dan Ryaas Rasyid, Otonomi Daerah Dalam Negara Kesatuan, Pustaka Pelajar, Yogyakarta, 2004.

\section{Kutipan Media Cetak.}

harian Kompas, 26 November 2010.

harian Kompas, 14 Desember 2010. 
Fiat Justitia Jurnal Ilmu Hukum Volume 6 No. 1 Januari-April 2012, ISSN 1978-5186

harian Media Indonesia, 01 Februari 2011 .

harian Kompas, 8 Pebruari 2011.
Saldi Isra, Haruskah Kembali Ke DPRD?, harian Kompas, 16 Desember 2010.

Syamsuddin Haris, Memperkuat Peran Gubernur, "Opini", harian Kompas, 26 November 2010. 